\title{
Naval Warfare 4.0: Joint and Combined, Manned or Unmanned-What Shapes the Future?
}

\author{
Tom Guy
}

"History does not repeat itself, but it does rhyme."-Mark Twain

\section{Introduction}

Predicting the future of warfare has always been both a necessary and precarious undertaking. Today, the rate of change in our world is accelerating, driven by technological advances, exacerbating the challenges of trying to envisage the future of warfare. Nevertheless, whilst making predictions may be fraught with risk, some assessment of the future is vital, as alliances, states and non-state actors inevitably strive to gain or maintain relative advantage and develop the necessary strategy to do so. The intent here is to ask, from an alliance perspective, what shapes the future of maritime warfare?

In assessing the future, we must start at the present: Within a decade, the current focus on 'Great Power Competition'1 may well have been supplanted by a global collective endeavour to combat the effects and causes of climate change, or by the forecast of an approaching asteroid that may cause a new era of global extinction. However, we could also be fighting over the second-order consequences of one nation's cloud seeding; prudent military planning dictates that as long as NATO wishes to preserve the values by which its members live, perpetuating military advantage for the foreseeable future will drive strategy.

1 The renewal of Great Power Competition with Russia and increasingly China, challenging US-led Western dominance, was acknowledged in the Obama Administration's 2015 National Military Strategy and was placed at the centre of the Trump Administration's 2017 National Security Strategy and 2018 National Defense Strategy. See: O’Rourke, Ronald, "Renewed Great power Competition: Implications for Defense-Issues for Congress", Congressional Research Service Reports, Updated 27 January 2021, https://crsreports.congress.gov/product/pdf/R/R43838. 
As the alliance looks ahead, it sees increasing challenges to this military advantage; discussion about Great Power Competition is realistic and necessary, but not overly optimistic or over-confident. Whilst this narrative of competition drives dedication and energy in alliance planning and warfare development, it does not drive the same political imperative for extensive defence spending that would come with a strategic shock. Warfare development is perpetually an intimate balance of ends and means, with ambition driving, and curtailed by, available resources, with variables invariably politically driven. One of the most important factors, therefore, is always likely to be resources; the 'guns or butter' debate is perennial'iob]' and 'economy of force' will be an enduring principle of war.

When we are shaping the next generation of maritime warfare, and strategy, there are innumerable developments to consider, ranging from climate change to human migration, and the cultural evolution associated with it, to emerging technology and what we seek to do with it. While climate change and geopolitics will undoubtedly fundamentally affect our lives over time, they will probably largely change where and why warfare is conducted. The most significant factors in how warfare is conducted will almost certainly be driven by technological developments. Three themes dominate the journey from here to tomorrow: Firstly, the transformation in information technology, the effects of which have already been extraordinary over the past few decades, appears likely only to accelerate and become magnified in the near future. Secondly, the exploitation of autonomy, or near autonomy on land, on and under the sea, and in the air will proliferate. In the near future, this will enable and demand that maritime commanders fight in very different ways. Thirdly, driven by these factors, notions of 'jointness', domains and Command and Control (C2) will continue their evolution, adapting to the emerging requirements and developing capabilities of future commanders and planners. ${ }^{4}$

2 The perpetual debate on the relative national priorities of defence and social spending, the phrase 'guns or butter' is generally attributed to WW1 US Secretary of State William Bryan. See: Feehery, John, "Guns and butter”, The Hill, 2 December 2009, https://thehill.com/blogs/pundits-blog/economy-a-budget/70233-guns-and-bu tter.

3 Of the nine Principles of War commonly taught to alliance militaries, 'Economy of Force' is generally intended to be applied at the operational or tactical level, but in this sense is proposed as a strategic consideration. See: JP 3-0, Joint Operations, 17 January 2017, https://www.jcs.mil/Portals/36/Documents/Doctrine/pubs/jp3_0ch1. pdf?ver=2018-11-27-160457-910.

4 In allied doctrine, 'Joint' is defined as the “....activities, operations and organizations in which elements of at least two services participate." 'Combined' indicates 
The combined effect of these themes will radically change the battlefield of the future. However, there are limits. At the strategic level, artificial intelligence $(\mathrm{AI})$, the exploitation of big data and machine learning will undoubtedly play an increasingly important role in determining objectives and plans. ${ }^{5}$ Even so, in the foreseeable future, it seems implausible that humans will abdicate major decision-making altogether, and from a moral perspective, why and how war will be conducted will ultimately be a human decision. In determining the what, where and when of the Command Estimate, ${ }^{6}$ planners will also increasingly harness augmented decision-making tools, ${ }^{7}$ but the Operational Commander will still be human. Nevertheless, having set the parameters for a morally acceptable conflict, and determined that the plan adheres to the principles of Jus ad bellum, the Operational Commander will undoubtedly rely upon increasingly autonomous capability to deliver effect that is jus in bello. ${ }^{8}$

the "...activities, operations and organizations in which elements of more than one nation participates." Allied doctrine defines five operational_domains': land, sea, air, space and cyberspace. See: Donnelly, Jared and Farley, Jon, "Defining the Domain in Multi-Domain", Joint Air and Space power Conference 2019, Shaping NATO for Multi-Domain Operations of the Future, 8 October 2019, https://www.japcc.org/de fining-the-domain-in-multi-domain/.

5 Artificial intelligence is generally used to denote the ability of a computer or computer-controlled robot to perform tasks commonly associated with intelligent beings. Machine Learning is a branch of AI focused on building applications that learn from data and improve their accuracy over time without being programmed to do so. The term big data was formally recognised in 2013 to describe computing data of a very large size, typically to the extent that its manipulation and management present significant logistical challenges, or put simply, sets of information that are too large or complex to handle, analyse or use with standard methods. See: IBM Cloud Education, https://www.ibm.com/cloud/learn/machine-learning.

6 The conceptual framework for military planners, the 'Command Estimate' is a sixstep iterative process defined in NATO doctrine.

7 Augmented decision-making uses automated analytics for the purpose of informing better, data-driven decisions. See: Burton, Jason, "Algorithms for Simpler Decision-Making (1 / 2): The Case for Cognitive Prosthetics”, The Decision Lab, https:// thedecisionlab.com/insights/society/towards-augmented-decision-making-12/.

8 Jus ad bellum describes the conditions under which states may resort to war or the use of armed forces in general. Jus in bello regulates the conduct of parties engaged in an armed conflict. See: International Committee of the Red Cross, "What are jus ad bellum and jus in bello?" 22 January 2015, https:/www.icrc.org/en/documen t/what-are-jus-ad-bellum-and-jus-bello-0. 


\section{Information - challenge or opportunity?}

It is perhaps one of the paradoxes of modern, and future, warfare that everimproving awareness enabled by technology does not necessarily equate to greater clarity of what is actually going on. Whilst the manipulation of information at all levels, from the tactical feint to strategic misinformation, is nothing new, the 'information age' has fundamentally changed the importance of information management in the battle space and the Information Operations campaign. At the tactical and operational levels, stealth technology, electronic deception and cyber warfare all provide hitherto inconceivable variables on an ever more networked battlefield. With an everincreasing reliance on the estimated 50 billion devices connected to the internet of things, and the continued evolution of the 'infosphere', 9 the increase in flow of information is almost unimaginable, but the corollary to that is that the cyber domain is likely to be one of the most keenly contested battlefields of the future. ${ }^{10}$ At the strategic level, individuals' connectivity and access to information globally has made the narrative a profoundly more potent weapon. ${ }^{11}$ In the maritime domain, this ubiquitous connectivity will enable previously 'out of sight and out of mind' activity to play a greater role in the narrative. In the North Atlantic context, the 'distant blockade' of WW1 12 and the 'wolf packs' of WW2 both had a profound strategic effect, ${ }^{13}$ which was felt ultimately on land, but were conducted entirely out of sight of the general populace. Whilst one can only speculate how earlier commanders would have behaved, or would have been al-

9 For an in-depth analysis of NATO's view on trends in this field, see Reding, D F and Eaton, J, "Science and Technology Trends 2020-2040", Exploring the S\&T Edge, NATO Science and Technology Organization, https://www.nato.int/nato_st atic_fl2014/assets/pdf/2020/4/pdf/190422-ST_Tech_Trends_Report_2020-2040.pd f.

10 Grigore, Neculai, "Naval Operations - C2 Cyber Protection of Maritime Unmanned Systems", CJOS COE, Jan 2021, www.cjoscoe.org.

11 Klingova, Katarina and Milo, Daniel, "Countering Information War Lessons Learned from NATO and Partner Countries: Recommendations and Conclusions", https://www.globsec.org/publications/countering-information-war-lessonslearned-nato-partner-countries-recommendations-conclusions/.

12 This Distant Blockade was the British blockade of the North Sea from 1914-1919, which sought to obstruct Germany's ability to import goods. Janicki, David A. 2014, “The British Blockade During World War I: The Weapon of Deprivation", Inquiries Journal/Student Pulse 6 (06), http://www.inquiriesjournal.com/articles/89 9/the-british-blockade-during-world-war-i-the-weapon-of-deprivation.

13 The term 'wolf pack' describes the tactic of coordinated submarine attacks on convoys. 
lowed to behave, with greater (and more immediate) public scrutiny of their actions, there is no doubt that modern and future media will make the presentation of action at, over and from the sea more important than ever, and this must be a key factor in shaping future strategy.

Differing perspectives on international behaviour will continue to drive competing blocs to take contrasting approaches to shaping the balance of power. Hybrid, grey-zone or sub-threshold activity offers attractive opportunities for greater 'economy of force', precisely because it undercuts the norms and values of acceptable international relations. ${ }^{14}$ Given the principles on which the alliance is established, hybrid warfare will therefore continue to be something that NATO needs to counter, not wage. Command of the information space will be the ultimate aim on both sides, but even as the global order evolves, alliance strategy must start with the moral high ground as its vital terrain. With more 'kinetic' activity delegated to carefully orchestrated autonomous, or largely autonomous units, Commanders on both sides will focus proportionately more effort on 'out-messaging' the opponent.

It is not only the flow of information from the battle space to the populace that will continue to burgeon, but also the flow of information within and across the battle space. At the tactical and operational levels, ${ }^{15}$ Command and Control in a Denied or Degraded Environment (C2DE) ${ }^{16}$ will be one of the greatest challenges in the near future as technology-en-

14 Hicks, Kathleen H. et al., "By other means. Part 1: Campaigning in the Gray Zone", Center for Strategic and International Studies, July 2019, https://csis-websi te-prod.s3.amazonaws.com/s3fs-public/publication/Hicks_GrayZone_interior_v4_ FULL_WEB_0.pdf.

15 In alliance doctrine, the strategic level is the "...level at which a nation or group of nations determines national or multinational security objectives and deploys national, including military, resources to achieve them." The operational level is the “... level at which campaigns and major operations are planned, conducted and sustained to accomplish strategic objectives within theatres or areas of operations." The tactical level is the "... level at which activities, battles and engagements are planned and executed to accomplish military objectives assigned to tactical level formations and units.", defined in Allied Administrative Publication 6, NATO Glossary of Terms and Definitions, Edition 2013, NATO Standardisation Agency, 2013, https://www.jcs.mil/Portals/36/Documents/Doctrine/Other_Pubs/a ap6.pdf.

$16 \mathrm{C} 2 \mathrm{D} 2 \mathrm{E}$ is the 'exercise of authority and direction by a commander over assigned and attached forces, in the accomplishment of a mission, while access to and use of critical information, systems and services are reduced or prevented'. Defined in Joint Publication 3-32, Command and Control for Joint Maritime Operations, 8 August 2006, https://fas.org/irp/doddir/dod/jp3_32ch1.pdf. 
abled high fidelity breeds reliance on data-rich information and centralised command and control. The current commander is already concerned with all aspects of warfare within his assigned geographical area 'from the seabed to space'; ${ }^{17}$ the future commander will have both the capability and the requirement to manage ever greater levels of complexity at greater pace. On the one hand, this proliferation of information in the battle space will make analysis harder; on the other, machine learning and augmented decision-making will ameliorate this, making it simply an extension of the arms race, but in a different form: the 'information race'. While the alliance quite rightly focuses on this challenge, it tends to view information as an enabler, but particularly in the context of the increasing need to counter 'hybrid' or 'sub-threshold' activity, its role as a disabler is equally powerful. In this context, distributed, networked unmanned systems in all domains could certainly provide 'economy of force' for the Maritime Commander both offensively and defensively.

The near-future maritime commander will have a battle space that is inextricably linked across the domains; assets and effects from other domains, including space and cyberspace, will influence the maritime environment, and the maritime commander will seek to influence events in the air, on land or in space, as well as at sea. Whilst that may not seem very unfamiliar, garnering, protecting and processing information across all domains faster and more effectively than the competitor will be the battlewinning edge of the near future. However, the need for resilience and the 'fallback' capability in a denied environment must be carefully considered as the evolution towards cyber-dependency continues.

Information management in all its forms will undoubtedly be at the heart of warfare development and planning across all domains. Nevertheless, future maritime warfare will not solely be in support of the information campaign. Whilst ultimately 'the seat of purpose is on the land', ${ }^{18}$ in a near-future conflict, the 'vital ground' of the maritime domain still seems likely to be vessels (increasingly autonomous) carrying vital cargoes, cables carrying vital data and pipelines carrying vital fuel. These 'Strategic Lines of Communication', will not only be of enduring importance to the military commander, but have enmeshed themselves in the existence of mod-

17 Vice Admiral Andrew L. Lewis, Commander US SECOND Fleet, quoted in Ackerman, Robert K, "Joint Force Takes on the New Ice Age", AFCEA Signal, 16 October 2020, https://www.afcea.org/content/joint-force-takes-new-ice-age.

18 Wayne P. Hughes Jr, "Naval Operations: A close look at the operational level of war at sea" in Naval War College Review vol. 65, No. 3 (Summer 2012), https://digi tal-commons.usnwc.edu/nwc-review/vol65/iss3/. 
ern society to the degree that they will be of truly great strategic value to regimes and populations at large. The battle to protect or degrade them will be a key element of future strategy.

\section{Man and machine in perfect harmony?}

It is no secret that harnessing autonomy is a top priority for NATO ${ }^{19}$ The combination of the ability of more-or-less unmanned systems to do well what humans struggle to achieve, and the promise of achieving effect at the expense of fewer humans, both in terms of peacetime resources and cost of life in conflict, is simply too compelling to ignore. In the maritime environment, the challenges of locating ever quieter submarines is already driving a quest for autonomous, or near-autonomous, undersea vehicles, able to operate persistently at range with an increasing array of ever more sensitive sensors, augmented by AI. ${ }^{20}$ While, as long as there are manned submarines, it seems likely that the principles of jus in bello will limit the degree to which targets are engaged without at least a person on the loop, if not in the loop, ${ }^{21}$ the opportunities for efficient and effective wide-area ASW are self-evident. In the defence of the extensive critical infrastructure in the maritime domain, UUVs in particular will be increasingly valuable in detecting and countering sub-threshold malign activity. ${ }^{22}$ In the same way that the air domain has now begun to embrace the use of unmanned systems more widely, remotely controlled or more or less autonomous vehicles, which are smaller, cheaper and able to be used in a broader opera-

19 Brussels Summit Declaration, issued by the Heads of State and Government participating in the meeting of the North Atlantic Council in Brussels 11-12 July 2018, Press Release (2018) 074, 11 July 2018, https:/www.nato.int/cps/en/natohq/o fficial_texts_156624.htm.

20 "Thirteen Allies to cooperate on the introduction of Maritime Unmanned Systems", NATO Head Quarters Newsroom/News online, 4 October 2018, https://www. nato.int/cps/en/natohq/news_158672.htm?selectedLocale=en.

21 Functions that have a man-in-the-loop require a positive affirmation from the human operator for the machine to proceed. In Man-on-the-loop functions, the operator need not approve of the machine's action beforehand but retains the ability to veto it before the execution, or abort once it has begun. United States DoD Directive 3000.09: Autonomy in Weapon Systems, Washington: DoD, 21 November 2012, pages 13-14, https://www.esd.whs.mil/Portals/54/Documents/DD/issuances/dodd/ 300009 p.pdf.

22 For an example of this emerging technology see a description of the Boeing Orca XLUUV at: https://www.naval-technology.com/projects/orca-xluuv/. 
tional risk envelope, are likely to proliferate at an increasing rate across the maritime domain, both in offensive and defensive roles. Whilst ultimately the 'Q-Ships' of WW1 really just accelerated the German embrace of unrestricted submarine warfare, tactically the concept was sound and there were some notable early successes.obis As autonomy proliferates, 'Q-Drones', armed and lethal, but virtually impossible to distinguish from the innumerable delivery and surveillance drones, could confer a huge tactical advantage, at a relatively low cost, with no risk to life and without ceding moral superiority.

Even if evolutionary changes in species are generally measured over generations and millennia, there can be no denying that the pace of technological advances is forcing a rapid shift in human behaviour, and what might have been considered science fiction a few years ago is now a realistic prospect within the lifetimes of many of our sailors. ${ }^{23}$ Wearable neurotechnologies are already here and offer extraordinary opportunities in efficiency and effectiveness in military applications. ${ }^{24}$ This abundance of civilian innovation provides military thinkers with new ideas relatively cheaply, thus accelerating the pace of change. Persistent Intelligence, Surveillance and Reconnaissance (ISR), enabled by civilian space capabilities, autonomy, driven by manufacturing and commerce, and information supported by machine learning are all extraordinary opportunities that are already being seized and are shaping the current, as well as the next, generation of maritime warfare.

Ubiquitous ISR and exquisite analysis, advancing almost exponentially, has engendered an expectation of clarity and precision of information in the battle space. While this may be a dangerous mirage, targeting decisions rely increasingly on real-time imagery, both in terms of delivering effect and in meeting politically acceptable standards of collateral damage that are defensible on the world media stage. Coupled with this, greater levels of remote scrutiny have eroded previously held notions of 'Mission Command'. ${ }^{25}$ There is an irony here that as the human race strives to create greater autonomy in machines, it is, at the same time, reducing the au-

23 Yuval Noah Harari, "Homo Deus, A Brief History of Tomorrow" (Vintage, 2017).

24 "Six paths to the Nonsurgical Future of Brain-Machine Interfaces", Defense Advanced Research Projects Agency, Outreach@Darpa.mil, 20 May 2019, https://ww w.darpa.mil/news-events/2019-05-20.

25 Mission Command is the principle of empowering subordinate decision-making and decentralised execution appropriate to the situation, defined in US Army Doctrine Publication No. 6 (ADP 6-0) Mission Command, 31 July 2019, https://fa s.org/irp/doddir/army/adp6_0.pdf. 
tonomy of our people. While it may be tempting to conclude that the days of Mission Command are truly behind us, made obsolete by technology, its importance as a concept endures: The commander of the future will apply the principles of mission command as he directs his team in setting the parameters for their autonomous aerial surveillance cordon or underwater search plan. They will already have determined whether to use manned, unmanned or selectively manned vehicles, and under what criteria. Locating and identifying an adversary will be achieved far better by machines; deciding what to do as a result will either be achieved through a pre-programmed algorithm within the autonomous system, or by a human being 'on the loop'. In either event, human presence in the battlefield will not be needed to deliver kinetic effect. The presence of a human being in a military unit will almost certainly be to deliver a specifically human effect, either for humanitarian reasons or in support of a particular narrative. There may well be a greater density of military hardware in the battle space, as machines that can fight, but do not need to protect or sustain humans, become cheaper and therefore more plentiful, but there will almost certainly be a far lower density of people directly in harm's way. This push-button violence at range makes maritime warfare a less personal affair. While the commander may be less cautious about committing to an action, in the knowledge that only treasure and not blood will be spilt, they will still need to consider the far-reaching effects of, for example, denying a wintry Northern Europe its entire supply of tanker-delivered liquefied natural gas.

\section{Combined and Joint, Multi-Domain, Cross-Domain... or Domain-agnostic?}

As technology, and connectivity in particular, should enable greater shared global awareness and therefore equality and unity, there is nevertheless, little to indicate that the world is becoming more peaceful. Equally, while one could extrapolate towards a global race, the human instinct to identify itself according to sub-divisions in race or nations appears to endure. However, whilst the maintenance of national identities seems inevitable, the advantages of alliance are also enduring. Returning to the initial point on 'economy of force', alliances have been a fact of warfare throughout history, and while they will morph, there does not appear anything to indicate that the concept will not endure for as long as the notion of nation statehood. So in the context of alliance strategy, 'combined' will continue to be an inherent feature of strategy. Nevertheless, the basic building block of defence continues to be the nation state, and while nations form alliances based on shared values and objectives, national interests invariably trump 
alliance goals when it comes to developing and maintaining military capability. Yes, future warfare will be 'combined', but the eternal quest for alliance interoperability will continue, as nations balance their own internal drivers and resources with those of their allies' collective objectives in developing their forces and doctrine. Technology is likely to widen capability disparities and exacerbate interoperability challenges; allied strategy will need to effectively employ a broader technical range of capabilities.

Within nations, the division of forces into domain-orientated services is arguably simply a convenient way of carving up organisations into more manageable chunks better able to focus on a specific range of tasks. Whilst previous attempts to dilute single-service identities have not been successful, future forces will need to be, and be able to be, far more cognisant of what is going on across all domains. ${ }^{26}$ Warfare at, and from, the sea is already an inherently multi-domain endeavour, and the effective maritime commander is instinctively 'joint' in outlook. As the combined effects of technological advances continue to enable seamless awareness and activity in, and affected by, space, the air, land, sea and cyber domains, future commanders will need to carefully harness available information and not only think in combined and joint terms, but evolve to be 'domain-agnostic' in their thinking.

Nevertheless, the physical differences between domains endure, and whilst Homo sapiens will continue to evolve, fundamentally our way of interacting within the domains will probably not change significantly in the near future. Continuing to define specifically 'Maritime' strategy, therefore has enduring utility. However, in the same way that the NATO Command Structure has evolved, i.e. that maritime strategy will be inherently subordinate to a geographically focused strategy, which defines activity across all domains, and in dealing with the 'maritime' domain, will be intrinsically linked to activity and factors in the others.

And so...

The maritime strategist of the future is likely to have to contend with a battle space that seems smaller, owing to continued advances in speed, range

26 Reilly, Jeffrey M., "Multidomain Operations: A Subtle but Significant Transition in Military Thought.", Air and Space Power Journal, vol. 30, issue 1, 1 March 2016, https://www.airuniversity.af.edu/ASPJ/Display/Article/1152102/volume-30-issue-1spring-2016/. 
and precision. But, at the same time, that battle space will be far denser, as sensors and information grow exponentially, reinforcing the interdependence between what happens under, on and over the sea, i.e. cross-domain. They will have to deal with the paradox of far greater access to information countered by a greater difficulty in discerning the truth; technology will not make the fog of war any less impenetrable. Seeing through this fog will not just be a challenge for the military commander, but also observers and political decision makers. Strategy will need to exploit technology in portraying maritime action, as the ubiquity of media drives the importance of the narrative ever further to the fore.

With so much exciting innovation proceeding at an ever increasing pace, it is tempting to think that warfare in the maritime domain will be unrecognisable in a few years, but, in the near future, without a significant strategic shock, humans will still want to be on the loop at least. The exploitation of information, at all levels and seamlessly across all domains, will be key. Efficiency, both physical and cognitive, will provide the battlewinning edge. Alliance Maritime Strategy will need to define the fundamentals of extensive manned and unmanned networks of sensors and shooters, and apply those to the geography of the NATO area of influence, in a way which ensures that what happens in the maritime domain seamlessly supports, and is supported by, what happens in all other domains. The fundamental challenge for future maritime strategy is the same as it has always been: adopting and adapting the latest tools and techniques to deal with emerging challenges. Inherent in this is the need to balance the ability to exploit new and exquisite technical capabilities with retaining resilience through the ability to operate without them when denied. Whilst one would not choose to do without every technological advantage, resilience will be critical to success. Strategy will need to exploit superior capability, but tactics will need to be able to do without it. Si vis pacem, para bellum will remain the successful mantra for a defensive alliance. ${ }^{27}$

\section{Works Cited}

Ackerman, Robert K., "Joint Force Takes on the New Ice Age", AFCEA Signal, 16 October 2020, https://www.afcea.org/content/joint-force-takes-new-ice-age.

27 Acknowledgements: I am indebted to the CJOS COE team for their support, in particular CDR Josh Heivly USN and LCDR Jesse Nerius USN. 
Alisferis, Dimosthenis, "An analysis of Potential Use of Unmanned Surface Vehicles (USV) In Sea Control Activities”, Combined Joint Operations from the Sea Centre of Excellence, January 2021, http://www.cjoscoe.org/infosite/wp-content/ uploads/2021/01/An-Analysis-Of-Potential-Use-Of-Unmanned-Surface-Vehicles-i n-Sea-Control-Activities.pdf.

Allied Administrative Publication 6, NATO Glossary of Terms and Definitions, Edition 2013, NATO Standardisation Agency, 2013, https://www.jcs.mil/Portals/36/Doc uments/Doctrine/Other_Pubs/aap6.pdf.

Bonnar, Todd, "More Tools in the Toolbox: Increasing Resiliency Through Commercially Sourced Assets for Space Based Maritime Situational Awareness", Combined Joint Operations from the Sea Centre of Excellence, December 2020, http:/www.cjoscoe.org/infosite/wp-content/uploads/2021/01/Increasing-Resilien cy-Through-Commercially-Sourced-Assets-for-Space-Based-Maritime-SituationalAwareness.pdf.

Burton, Jason, "Algorithms for Simpler Decision-Making (1 / 2): The Case for Cognitive Prosthetics”, The Decision Lab, https://thedecisionlab.com/insights/societ y/towards-augmented-decision-making-12/.

"Six paths to the Nonsurgical Future of Brain-Machine Interfaces", Defense Advanced Research Projects Agency, Outreach@Darpa.mil, 20 May 2019, https://w ww.darpa.mil/news-events/2019-05-20.

Donnelly, Jared and Farley, Jon, "Defining the Domain in Multi-Domain", Joint Air and Space power Conference 2019, Shaping NATO for Multi-Domain Operations of the Future, 8 October 2019, https://www.japcc.org/defining-the-domain-in-mul ti-domain/.

Feehery, John, “Guns and butter”, The Hill, 2 December 2009, https://thehill.com/b logs/pundits-blog/economy-a-budget/70233-guns-and-butter.

Grigore, Neculai, "Naval Operations - C2 Cyber Protection of Maritime Unmanned Systems", CJOS COE, January 2021, www.cjoscoe.org.

Harari, Yuval Noah, "Homo Deus, A Brief History of Tomorrow", Vintage, 2017.

Haynes, Peter D, “Towards a New Maritime Strategy”, US Naval Institute, 2015, https://www.usni.org/press/books/toward-new-maritime-strategy.

Hicks, Kathleen H. et al., "By other means. Part 1: Campaigning in the Gray Zone“, Center for Strategic and International Studies, July 2019, https://csis-web site-prod.s3.amazonaws.com/s3fs-public/publication/Hicks_GrayZone_interior_ v4_FULL_WEB_0.pdf.

Huls, Jay and David, Guillermo, "Big Data: Maritime Uses and Challenges”, Combined Joint operations from the Sea Centre of Excellence, June 2019, http://ww w.cjoscoe.org/infosite/wp-content/uploads/2019/06/Big_Data_Maritime_Uses_a nd_Challenges-1.pdf.

IBM Cloud Education, https://www.ibm.com/cloud/learn/machine-learning.

International Committee of the Red Cross, "What are jus ad bellum and jus in bello?”, 22 January 2015, https://www.icrc.org/en/document/what-are-jus-ad-bellum -and-jus-bello-0. 
Janicki, David A. 2014, “The British Blockade During World War I: The Weapon of Deprivation", Inquiries Journal/Student Pulse 6 (06), http://www.inquiriesjournal. com/articles/899/the-british-blockade-during-world-war-i-the-weapon-of-deprivat ion.

Joint Publication 3-0, Joint Operations, US Department of Defense, 17 January 2017, https://www.jcs.mil/Portals/36/Documents/Doctrine/pubs/jp3_0ch1.pdf?ver=201 8-11-27-160457-910.

Joint Publication 3-32, Command and Control for Joint Maritime Operations, 8 August 2006, https://fas.org/irp/doddir/dod/jp3_32ch1.pdf.

Klingova, Katarina and Milo, Daniel, "Countering Information War Lessons Learned from NATO and Partner Countries: Recommendations and Conclusions", https:/www.globsec.org/publications/countering-information-war-lesson s-learned-nato-partner-countries-recommendations-conclusions/.

Martin, Jean Yves, "Study on Multi-Domain Operations in the Maritime Domain", Combined Joint Operations from the Sea Centre of Excellence, January 2021, http:/www.cjoscoe.org/infosite/wp-content/uploads/2021/01/Study-on-Multi-Do main-Operations-in-the-Maritime-Domain.pdf.

NATO Press Release (2018) 074, 11 July 2018, https:/www.nato.int/cps/en/natohq/of ficial_texts_156624.htm.

NATO Head Quarters Newsroom/News online, 4 October 2018, https://www.nato.int/ cps/en/natohq/news_158672.htm?selectedLocale=en.

Naval Doctrine Publication 1, Naval Warfare, US Navy Warfare Development Command, 15 April 2020.

Naval-History.net. "British Special Service or Q Ships”, https://www.naval-history.n et/WW1NavyBritishQships.htm.

O'Rourke, Ronald, "Renewed Great power Competition: Implications for Defense - Issues for Congress”, Congressional Research Service Reports, updated 27 January 2021, https://crsreports.congress.gov/product/pdf/R/R43838.

Patti, Roberto, "Joint Operations with Unmanned Aircraft Systems (UAS) and their Future Development”, Combined Joint Operations from the Sea Centre of Excellence, January 2021, http://www.cjoscoe.org/infosite/wp-content/uploads/2 021/01/Joint-Operations-with-Unmanned-Aircraft-Systems-and-their-Future-Dev elopment.pdf.

Reding, D. F. and Eaton, J., “Science and Technology Trends 2020-2040”, Exploring the S\&T Edge, NATO Science and Technology Organization, https://www.nato.i nt/nato_static_fl2014/assets/pdf/2020/4/pdf/190422-ST_Tech_Trends_Report_20 20-2040.pdf.

Reilly, Jeffrey M., "Multidomain Operations: A Subtle but Significant Transition in Military Thought.", Air and Space Power Journal, vol. 30, issue 1, 1 March 2016, https:/www.airuniversity.af.edu/ASPJ/Display/Article/1152102/volume-30-issue1-spring-2016/.

Scott, Stephen, "Denied C2 Environments", Cutting the Bow Wave, Combined Joint operations from the Sea Centre of Excellence, February 2021, www.cjoscoe.org. 
United States DoD Directive 3000.09: Autonomy in Weapon Systems, Washington: DoD, 21 November 2012, pages 13-14, https://www.esd.whs.mil/Portals/54/Doc uments/DD/issuances/dodd/300009p.pdf.

US Army Doctrine Publication No. 6 (ADP 6-0) Mission Command, 31 July 2019, https://fas.org/irp/doddir/army/adp6_0.pdf.

Wayne P. Hughes Jr, "Naval Operations: A close look at the operational level of war at sea" in Naval War College Review vol. 65, No. 3 (Summer 2012), https://di gital-commons.usnwc.edu/nwc-review/vol65/iss3/. 